\title{
Deteksi Bakteri Staphylococcus sp. dari Saluran Pernapasan Babi
}

\section{(DETECTION OF STAPHYLOCOCCUS SP. FROM THE PIG RESPIRATORY TRACT)}

\author{
Makselina Ayu Dwi Purwanti ${ }^{1 *}$, I Nengah Kerta Besung², I Gusti Ketut Suarjana ${ }^{2}$ \\ ${ }^{1}$ Praktisi Dokteran Hewan di Denpasar-Bali, ${ }^{2}$ Laboratorium Bakteriologi dan Mikologi \\ Veteriner, Fakultas Kedokteran Hewan Universitas Udayana. Denpasar, Bali. \\ *Email: makselinaayu21@gmail.com
}

\begin{abstract}
ABSTRAK
Penelitian ini dilakukan untuk mendeteksi Staphylococcus sp. di saluran pernapasan babi. Sampel dibedakan berdasarkan jenis kelamin (babi jantan dan babi betina). Sebanyak 100 sampel usapan hidung dikumpulkan secara aseptik dari babi yang menunjukkan gejala penyakit respirasi, yang diambil dari peternakan babi di daerah Badung dan Tabanan. Semua sampel ditanam pada media Blood Agar selama $18-24$ jam pada suhu $37^{\circ} \mathrm{C}$. Koloni yang dicurigai kemudian dilakukan pewarnaan Gram, uji primer (uji katalase dan oksidase), dan serangkaian tes biokimia. Analisis statistik (Chi-square) dilakukan untuk mengetahui perbedaan jumlah sampel positif Staphylococcus sp. terisolasi antara babi jantan dan babi betina. Dari 100 sampel, tujuh sampel positif Staphylococcus sp. (enam dari babi jantan dan satu dari babi betina). Secara statistik, jumlah babi jantan yang terinfeksi Staphylococcus sp. lebih tinggi $(\mathrm{P}<0,01)$ dibandingkan dengan babi betina. Spesies Staphylococcus yang diisolasi adalah: Staphylococcus aureus, Staphylococcus epidermidis, dan Staphylococcus saprophyticus.
\end{abstract}

Kata kunci: Babi; Staphylococcus sp; usapan nasal

\section{ABSTRACT}

This research was conducted for the detection of Staphylococcus sp. in the respiratory tract of pigs. Samples differentiated by sex (male pigs and female pigs). A total of 100 nasal swab samples were collected aseptically from pigs showing symptoms of respiratory disease, from pig farms in the area of Badung and Tabanan. All samples were cultured on to Blood Agar for $18-24 \mathrm{~h}$ at $37^{\circ} \mathrm{C}$. Suspected colonies were then Gram staining, primary tests (tested for catalase and oxidase) and series of biochemical tests. Statistical analysis (Chi-square) was performed to explore the differences in positive samples numbers of Staphylococcus sp. isolated between male and female pigs. Of the 100 samples, seven positive samples of Staphylococcus sp. (six of the boars and one from the female pig). Statistically, the number of boars infected with Staphylococcus sp. higher $(\mathrm{P}<0.01)$ than with female pigs Staphylococcus species isolated were: Staphylococcus aureus, Staphylococcus epidermidis, and Staphylococcus saprophyticus, respectively.

Keywords: Nasal swab; pigs; Staphylococcus $s p$

\section{PENDAHULUAN}

Babi merupakan salah satu ternak yang mempunyai potensi sebagai sumber protein hewani yang bersifat prolifik atau beranak banyak dalam satu kali kelahiran bisa mencapai 8-12 ekor dengan rata-rata dua kali kelahiran per tahunnya (Siagian et al., 2004). Disamping itu, babi juga memiliki kesanggupan dalam mengkonversi bahan makanan secara efisien (Ardana, 2012). Ternak babi termasuk ke dalam ternak yang mudah dikembangbiakkan, dan memiliki nilai karkas yang cukup tinggi sebagai penyedia protein hewani. Daging babi memiliki kelebihan daripada ternak lainnya, yaitu tekstur daging yang lebih empuk, dan banyak dicari oleh konsumen untuk kebutuhan sehari-hari maupun untuk acara keagamaan, terutama pada daerah yang mayoritas penduduknya non muslim seperti di Bali (Kardena et al., 2012; Agustina et al., 2017)

Data populasi ternak babi di Indonesia tahun 2011 sampai 2015 mengalami ketidak stabilan. Jumlah ternak babi tahun 2011 yaitu 7.524.787 ekor, tahun 2012 yaitu 7.900.363 ekor, tahun 2013 mengalami penurunan menjadi 7.598.694 ekor, tahun 2014 lebih meningkat dari tahun 2013 yaitu 7.694.130 ekor, dan tahun 
2015 mengalami peningkatan cukup signifikan yaitu 8.043 .795 ekor. Adanya peningkatan populasi ini menandakan bahwa konsumsi daging babi terus meningkat. Permintaan daging babi yang semakin meningkat tidak hanya dari dalam negeri melainkan juga dari luar negeri seperti kawasan Asia Timur. Di Bali, populasi babi mengalami penurunan dari tahun ke tahun yaitu pada tahun 2011 populasi sebanyak 922.739 ekor dan mengalami penurunan pada tahun 2015 sebanyak 825.658 ekor. Khusus untuk daerah Tabanan, jumlah populasi babi tahun 2015 mencapai 150.945 ekor, dan untuk daerah Badung jumlah populasi babi tahun 2015 mencapai 107.770 ekor. Jumlah ternak babi yang dipotong pada tahun 2015 mencapai 2.156.564 ekor. Jumlah ini sangat meningkat dibandingkan jumlah ternak babi yang dipotong pada tahun 2014 yaitu 1.795.822 ekor. Hal ini membuktikan bahwa konsumsi daging babi di Bali terus meningkat (Badan Pusat Statistika, 2016).

Jumlah konsumsi daging babi yang meningkat setiap tahunnya berbanding terbalik dengan jumlah populasi ternak babi di Bali yang mengalami penurunan (Agustina et al., 2016). Menurunnya populasi ternak babi di Bali karena peternak babi di Bali masih menerapkan sistem pemeliharaan secara tradisional hingga semi intensif. Pakan yang diberikan kurang memperhatikan nilai gizi dan faktor higienis. Selain itu juga lingkungan kandang yang buruk seperti lantai kandang yang jarang dibersihkan sehingga tampak kotor dan becek. Cara pemeliharaan ternak babi seperti inilah yang masih rentan terhadap infeksi dari berbagai macam penyakit (Agustina, 2013). Beberapa penyakit yang dapat menyerang babi adalah bakteri, virus, parasit, dan jamur. Beberapa agen penyakit ini dapat tumbuh di saluran pernapasan.

Saluran pernapasan merupakan tempat pertumbuhan beberapa bakteri flora normal dan suatu saat bakteri ini dapat menjadi patogen. Menurut Baele et al. (2001) beberapa bakteri flora normal yang terdapat pada saluran respirasi atas pada babi seperti hidung dan tonsil diantaranya yaitu Streptococcus suis, Rothia nasimurium, Lactobacillus, Streptococcus dysgalactiae, Staphylococcus hycus, Staphylococcus aureus, Arcanobacterium pyogenes dan Actynomyces hyovaginalis. Diantara beberapa bakteri flora normal tersebut, terdapat beberapa bakteri yang berpotensi patogen pada saluran pernapasan babi diantaranya yaitu Streptococcus suis, Streptococcus dysgalactiae, dan Staphylococcus aureus. Selain itu, Chotiah (1996) juga mengisolasi bakteri Pasterulla multocida dari lesi pneumonik pada paruparu babi.

Secara umum, jenis kelamin menjadi faktor resiko terhadap kejadian penyakit infeksi pada saluran pernapasan (Iskandar et al., 2015). Hormon estrogen pada babi betina dapat memacu sel-sel fagosit untuk melakukan fagositosis. Aktivasi sel fagosit seperti makrofag menyebabkan perubahan kuantitatif dan kualitatif makrofag. Perubahan kuantitatif yaitu pertambahan jumlah makrofag yang ada di dalam tubuh. Hormon estrogen memacu pembelahan selsel makrofag. Perubahan kualitatif yaitu meningkatnya kemampuan fagosit makrofag, hal ini diakibatkan pengaruh hormon estrogen yang menyebabkan sensitisasi makrofag sehingga makrofag mampu melakukan fagositosis secara lebih efisien. Akibatnya ternak betina relatif lebih tahan terhadap berbagai jenis penyakit dibandingkan dengan ternak jantan (Zuk and Andrew, 2010).

Bakteri Staphylococcus merupakan flora normal pada kulit dan membran mukosa alat pencernaan dan pernapasan. Staphylococcus juga dapat ditemukan pada makanan seperti daging dan susu. Keganasan Staphylococcus untuk menginfeksi disebabkan oleh adanya substansi antigen maupun produksi toksin atau enzim (Quinn et al., 2002). Infeksi yang ditimbulkan oleh bakteri Staphylococcus ini diantaranya yaitu mastitis, abses, synovitis purulenta, dermafitis, endometritis, lesi disekitar 
mata, sampai terjadinya infeksi saluran kencing (Gotz et al., 2006).

Andresen et al. (2004) memaparkan bahwa bakteri Staphylococcus menyebabkan terjadinya eksudatif epidermitis pada babi di Denmark. Di Swis juga dilaporkan mengenai kejadian eksudatif epidermitis pada babi yang disebabkan oleh Staphylococcus (Casanova et al., 2011). Eksudatif epidermitis ditemukan juga pada peternakan babi di Swedia yang disebabkan oleh Staphylococcus (Denis et al., 2009). Eksudatif epidermitis ini mulai terlihat pada babi yang berusia dua minggu sampai enam minggu. Pada infeksi saluran pernapasan, Staphylococcus hanya menjadi penyebab sekunder. Seperti halnya yang dilaporkan oleh Smith et al. (2011) bahwa ditemukannya bakteri Staphylococcus menjadi penyebab sekunder dari influenza pada babi di USA.

Kejadian penyakit akibat Staphylococcus pada babi sudah banyak dilaporkan di berbagai negara, terutama kejadian penyakit kulit. Sebagai penyebab infeksi pada saluran pernapasan sejauh ini hanya sebagai penyebab sekunder. Di Indonesia khususnya Bali, infeksi saluran pernapasan babi akibat Staphylococcus belum pernah dilaporkan. Sehingga informasi mengenai kejadian Staphylococcus pada saluran pernapasan babi penting untuk dilakukan.

\section{METODE PENELITIAN}

\section{Jenis Sampel}

Sampel penelitian yang digunakan adalah usapan nasal dari babi yang mengalami gangguan pernapasan. Babi berasal dari dua kabupaten yaitu Badung dan Tabanan. Sampel diambil secara aseptis kemudian disimpan dalam tabung mikro yang didalamnya sudah berisi transport media (Stuart Agar).

\section{Isolasi Bakteri}

Isolasi bakteri dilakukan pada media Blood Agar. Seluruh sampel usapan nasal babi ditanam pada media Blood Agar, kemudian diinkubasi pada suhu $37^{\circ} \mathrm{C}$ selama 18- 24 jam. Keesokan harinya identifikasi media tersebut dapat dilakukan meliputi bentuk, warna, tepian, dan diameter koloni.

\section{Identifikasi Bakteri}

Identifikasi bakteri yang dilakukan meliputi pengamatan morfologi koloni pada permukaan Blood Agar. Setelah itu dilakukan pewarnaan Gram, kemudian dilakukan uji primer (uji katalase dan oksidase), uji biokimia (uji koagulase, uji indol, dan uji VP). Untuk identifikasi akhir dilakukan uji gula-gula (glukosa, laktosa, maltose, dan sukrosa).

\section{Analisis Data}

Data tentang spesies Staphylococcus yang diisolasi dari saluran pernapasan babi dianalisis menggunakan analisis deskriptif. Perbedaan jumlah babi jantan dan betina yang terkena infeksi Staphylococcus sp. dianalisis dengan chi-square.

\section{HASIL DAN PEMBAHASAN}

Penelitian deteksi bakteri Staphylococcus $s p$. dari saluran pernapasan babi yang diambil dari dua kabupaten yaitu Tabanan dan Badung, pada babi jantan dan babi betina, hasilnya terlihat pada Tabel 1 .

Berdasarkan Tabel 1 diketahui bahwa jumlah sampel positif yang terdeteksi bakteri Staphylococcus sp. di daerah Badung dan Tabanan pada babi jantan dan babi betina yaitu tujuh ekor sampel (7\%). Jumlah sampel positif di daerah Badung pada babi jantan sebanyak 0 ekor $(0 \%)$ positif atau 35 ekor (100\%) negatif, pada babi betina sebanyak 1 ekor $(3,1 \%)$ positif atau 31 ekor $(96,9 \%)$ negatif. Sedangkan di daerah Tabanan pada babi jantan sebanyak 6 ekor $(35,3 \%)$ positif atau 11 ekor $(64,7 \%)$ negatif, pada babi betina sebanyak 0 ekor $(0 \%)$ positif atau 16 ekor (100\%) negatif. Data tersebut menunjukkan bahwa jumlah sampel positif yang terdeteksi bakteri Staphylococcus sp. pada babi jantan lebih tinggi dibandingkan pada babi betina. 
Data jumlah sampel terdeteksi bakteri Staphylococcus sp. pada saluran pernapasan babi yang dianalisis dengan Chi-square menunjukkan jumlah babi jantan yang terinfeksi Staphylococcus lebih tinggi sangat nyata dibandingkan dengan babi betina. Setelah identifikasi dengan beberapa uji yang mengacu pada buku Berkeley et al. (1993) terhadap tujuh sampel positif Staphylococcus didapatkan hasil uji pada Tabel 2.

Tabel 1 Jumlah sampel positif terdeteksi bakteri Staphylococcus sp. dari saluran pernapasan babi yang diambil dari dua Kabupaten di Tabanan dan Badung pada babi jantan dan betina.

\begin{tabular}{llllll} 
& \multicolumn{2}{c}{ Badung } & \multicolumn{2}{c}{ Tabanan } & \multirow{2}{*}{ Total } \\
\cline { 2 - 5 } & \multicolumn{1}{c}{$\begin{array}{c}\text { Jantan } \\
(\text { ekor })\end{array}$} & $\begin{array}{c}\text { Betina } \\
(\text { ekor })\end{array}$ & $\begin{array}{c}\text { Jantan } \\
(\text { ekor) }\end{array}$ & $\begin{array}{c}\text { Betina } \\
(\text { ekor) }\end{array}$ & \\
\hline Positif & $0(0 \%)$ & $1(3,1 \%)$ & $6(35,3 \%)$ & $0(0 \%)$ & $7(7 \%)$ \\
Negatif & $35(100 \%)$ & $31(96,9 \%)$ & $11(64,7 \%)$ & $16(100 \%)$ & $93(93 \%)$ \\
\hline Total & 35 & 32 & 17 & 16 & 100 \\
\hline
\end{tabular}

Tabel 2. Hasil uji primer, uji biokimia, dan uji gula-gula tujuh sampel positif Staphylococcus.

\begin{tabular}{|c|c|c|c|c|c|c|c|c|c|c|}
\hline \multirow{2}{*}{$\begin{array}{c}\text { NO } \\
\text { SAMPEL }\end{array}$} & \multirow[t]{2}{*}{ SPESIES } & \multicolumn{2}{|c|}{ Uji Primer } & \multicolumn{3}{|c|}{ Uji Biokimia } & \multicolumn{4}{|c|}{ Uji Gula-gula } \\
\hline & & Kat & Oks & Indol & VP & Koa & Glk & Lkt & Mlt & $\mathrm{Skr}$ \\
\hline $\operatorname{Alj}(1)$ & S. aureus & + & - & + & + & + & + & + & + & + \\
\hline $\operatorname{Alj}(2)$ & S. epidermidis & + & - & - & + & - & + & + & + & + \\
\hline $\mathrm{A} 1 \mathrm{~J}(3)$ & S. aureus & + & - & + & + & + & + & $\mathrm{V}$ & + & + \\
\hline Alj (4) & S. aureus & + & - & - & + & + & + & + & + & + \\
\hline Alj (5) & S. saprophyticus & + & - & - & - & - & - & + & + & + \\
\hline Alj (6) & S. aureus & + & - & - & + & + & + & + & + & + \\
\hline A2b (7) & S. saprophyticus & + & - & - & - & - & - & + & + & + \\
\hline
\end{tabular}

Keterangan: A1: Tabanan, A2: Badung, j: Jantan, b: Betina, Kat: Katalase, Oks: Oksidase, VP: Voges Proskauer, Koa: Koagulase, Glk: Glukosa, Lkt: Laktosa, Mlt: Maltose, Skr: Sukrose, v: variabel.

Tabel 2. menunjukkan bahwa hasil deteksi pada sampel A1j (1) yaitu Staphylococcus aureus, $\mathrm{A} 1 \mathrm{j}$ Staphylococcus epidermidis, A1j Staphylococcus aureus, $\mathrm{A} 1 \mathrm{j}$ Staphylococcus aureus, $\mathrm{A} 1 \mathrm{j}$ Staphylococcus saprophyticus, A1j (6) Staphylococcus aureus, dan A2b (7) Staphylococcus saprophyticus.

Berdasarkan penelitian yang dilakukan terhadap 100 sampel usapan nasal babi yang mengalami gangguan pernapasan yang diambil di daerah Badung dan Tabanan pada babi jantan dan betina, didapatkan jumlah sampel positif yang terdeteksi bakteri Staphylococcus sebanyak enam sampel pada babi jantan dan pada babi betina ditemukan sebanyak satu sampel. Hasil analisis Chi-square didapatkan bahwa jumlah babi jantan yang terinfeksi Staphylococcus sp. lebih tinggi sangat nyata dibandingkan dengan babi betina.

Ditemukannya bakteri Staphylococcus $s p$. pada saluran pernapasan babi karena bakteri Staphylococcus merupakan bakteri flora normal pada kulit, membran mukosa alat pencernaan, reproduksi, maupun membran mukosa pernapasan. Kemampuan bakteri Staphylococcus untuk masuk ke dalam tubuh dan menginfeksi tergantung beberapa faktor predisposisi seperti trauma pada kulit dan membran mukosa, infeksi virus, dan ketidakseimbangan flora normal. Adanya faktor predisposisi tersebut dapat menyebabkan bakteri flora normal seperti Staphylococcus menjadi berpotensi patogen. Bakteri Staphylococcus pada saluran pernapasan ini dapat menjadi 
patogen juga karena terdapat substansi antigen maupun produksi toksin atau enzim (Vasconcelos and Maria, 2010).

Kejadian infeksi yang berhubungan dengan jenis kelamin berkaitan dengan adanya hormon. Pada babi betina ditemukan hormon estrogen. Hormon ini memacu sel-sel fagosit untuk melakukan aktivasi. Aktivasi sel fagosit seperti makrofag menyebabkan perubahan kuantitatif dan kualitatif makrofag. Perubahan kuantitatif yaitu pertambahan jumlah makrofag yang ada di dalam tubuh. Hormon estrogen memacu pembelahan selsel makrofag. Perubahan kualitatif yaitu meningkatnya kemampuan fagosit makrofag, hal ini diakibatkan pengaruh hormon estrogen yang menyebabkab sensitisasi makrofag sehingga makrofag mampu melakukan fagositosis secara lebih efisien. Meningkatnya kemampuan kauntitatif dan kualitatif makrofag maka pelenyapan benda asing yang masuk ke dalam tubuh menjadi meningkat, sehingga babi betina lebih tahan terhadap agen penyakit dibandingkan babi jantan. Adanya hormon ini juga memacu sel-sel fagosit untuk melakukan fagositosis (Zuk and Andrew, 2010). Hasil analisis menggunakan Chi-square menunjukkan bahwa jumlah babi jantan lebih tinggi sangat nyata $(\mathrm{P}<0.01)$ dibandingkan babi betina terhadap infeksi Staphylococcus.

Hasil deteksi Staphylococcus sp. pada saluran pernapasan babi didapatkan tiga spesies yaitu empat sampel positif Staphylococcus aureus, dua sampel positif Staphylococcus saprophyticus, dan satu sampel positif Staphylococcus epidermidis. Staphylococcus aureus merupakan bakteri yang bersifat flora normal. Bakteri ini biasa terdapat pada saluran pernapasan atas dan kulit. Staphylococcus aureus merupakan bakteri patogen potensial. Bakteri ini dapat menjadi penyebab beberapa penyakit seperti mastitis, tiek pyemia, synovitis purulenta, dermafitis, dan endometritis (Harris et al., 2002). Staphylococcus saprophyticus merupakan bakteri oportunistik patogen. Bakteri ini dapat diisolasi dari lubang hidung hewan yang sehat. Staphylococcus saprophyticus sering ditemukan menjadi penyebab infeksi saluran kencing (Hajek, 1996). Staphylococcus epidermidis merupakan bakteri yang secara alami hidup pada kulit dan membran mukosa. Staphylococcus epidermidis sama seperti kedua spesies Staphylococcus lain seperti Staphylococcus aureus dan Staphylococcus saprophyticus yang bersifat oportunistik patogen. Ketiga spesies ini dapat menyebabkan infeksi karena resistensi inang yang melemah, ketidakseimbangan flora normal, adanya penyakit ataupun luka sehingga terjadinya pelemahan inang. Bakteri-bakteri tersebut dapat mencapai saluran pernapasan melalui inokulasi langsung, penyebaran pembuluh darah, inhalasi, maupun kolonisasi permukaan mukosa (Ribet and Pascale, 2015).

\section{SIMPULAN}

\section{Simpulan}

Telah berhasil dideteksi bakteri Staphylococcus sp. dari babi yang mengalami gangguan pernapasan. Ditemukannya tiga spesies bakteri Staphylococcus pada saluran pernapasan babi yaitu Staphylococcus aureus, Staphylococcus saprophyticus, dan Staphylococcus epidermidis. Jumlah babi jantan yang terkena infeksi Staphylococcus lebih tinggi sangat nyata dibandingkan babi betina

\section{Saran}

Perlu ditingkatkan kebersihan kandang, pemberian pakan yang berkualitas agar terhindar dari infeksi Staphylococcus. Perlu dicarikan obat yang tepat untuk menangani kejadian Staphylococcus pada babi.

\section{UCAPAN TERIMAKASIH}

Penulis mengucapkan terimakasih kepada Laboratorium Bakteriologi dan Mikologi Veteriner Fakultas Kedokteran Hewan Universitas Udayana, serta semua pihak yang telah membantu dalam proses penelitian ini. 


\section{DAFTAR PUSTAKA}

Agustina KK. 2013. Identifikasi dan Prevalensi Cacing Type Strongyle pada Babi di Bali. Bul. Vet. Udayana. 5(4): 131-138.

Agustina KK, Wirata IW, Dharmayudha AAGO, Kardena IM, Dharmawan NS. 2016. Increasing farmer income by improved pig management systems. Bul. Vet. Udayana. 8(2): 122-127.

Agustina KK, Sari PH, Suada IK. 2017. The influence of immersion into Indonesian bay leaf infusion to the quality and durability of pork. Bul. Vet. Udayana. 9(1): 34-41.

Andresen LO, Peter H, Lise D, and Vivi BH. 2004. Exudative Epidermitis in Pigs Caused by Toxigenic Staphylococcus Chromogenes. Veterinary Microbiology. 105:291-300. Ardana IBK. 2012. Penurunan Angka Morbiditas Dan Mortatiltas Anak Babi Yang Diberi Vitamin Dan Elektrolit Melalui Air Minum Saat Disapih. Bul. Vet. Udayana. 4(1): 33-40.

Badan Pusat Statistika. 2016. Provinsi Bali Dalam Angka 2016. Badan Pusat Statistika Provinsi Bali.

Baele M. 2001. The Gram-positive tonsillar and nasal flora of piglets before and after weaning. J. Appl. Microbiol. 91: 997-1003.

Berkeley, R, C, W., Colman, G., Fox, E., Gross, R., Holmes, B., Jenkins, P, A., Jones, D., Lea, J, V., Marples, R, R., Schofield, G, M., Scraton, M., Skirrow, M, B., Slack, M, P, E., Snell, J, J, S., and Willis, A, T. 1993. Cowan and Steel's Manual for The Identification of Medical Bacteria. $3^{\text {rd }}$ Ed. Cambridge University Press. USA.

Casanova C, Lukas I, Niklaus VS, Sara D, and Parham S. 2011. Staphylococcus hyicus Bacteremia in A Farmer. J. Clin. Microbiol. 49: 4377-4378.

Chotiah S. 1996. Isolasi, Identifikasi dan Penentuan Serotipe Isolat Pasteurella multocida dari Lesi Pneumonik ParuParu Babi dan Kepekaannya Terhadap
Beberapa Macam Antibiotika. J. Ilmu Ternak dan Vet. 2: 198-203.

Denis O, Carl S, Marie H, Boudewijn C, Ilse R., Marc D, Glenda W, Bart G, Patrick B, and Marc JS. 2009. Resistant Staphylococcus aureus ST398 In Swine Farm Personel Belgium. Emerg. Infect. Dis. 15:1098-1101.

Gotz F, Bannerman T, and Schleifer KH. 2006. The genera Staphylococcus and Macrococcus. The Prokaryotes 4: 5-75.

Hajek V. 1996. Staphylococcus saprophyticus subsp bovis subsp. Nov Isolated from Bovine Nostrils. Int. J. Systematic Bacteriol. 46:792-796.

Harris LG, Foster SJ, and Richards RG. 2002. An Introduction to Staphylococcus aureus, And Techniques for Identifying and Quantifying S. Aureus Adhesins In Relation To Adhesion To Biomaterials: Review. Europ. Cells and Materials. 4: 39-60.

Iskandar A, Suganda T, dan Lelly Y. 2015. Hubungan Jenis Kelamin dan Usia Anak Satu Tahun Sampai Lima Tahun dengan Kejadian ISPA. Global Med. Health Comm. 3: 1-6.

Kardena IM, Suarjana IGK, dan Udayani P. 2012. Studi Kasus Perhitungan Tingkat Morbiditas, Mortalitas, dan Fatalitas Kolibasilosis pada Babi yang Dipelihara Semi Intensif. Bul. Vet. Udayana. 4(1): 17-22.

Quinn et al., 2002. Veterinary Microbiology and Microbial Disease. Lowa state University press. USA.

Ribet D and Pascale C. 2015. How Bacterial Pathogens Colonize Their Hosts and Invade Deeper Tissues. Microbes and Infect. 17: 173-183.

Siagian PH, Priyanto R, dan Sembiring R. 2004. Kualitas Daging Babi Dengan Pemberian Zeolit dan Tepung Darah Sebagai Sumber Protein dalam Ransum. Media Peternakan. 27(1): 111.

Smith EA, Sandeep RPK, Jagadeeswaran D, Thomas EC, Tanya L, Mike M, Subbiah E, and Isis KM. 2011. A Time 
Course for Suspectibility To Staphylococcus aureus Respiratory Infection During Influenza in A Swine Model. Hindawi Pub. Corp. 1-10.

Vasconcelos NG and Maria LRSC. 2010.

Staphylococcal Enterotoxin: Molecular
Aspects and Detection Methods. J. Pub Health and Epidemiol. 2(3): 29-42.

Zuk M, and Andrew MS. 2010. Sex Hormones and Immunity to Infection. $1^{\text {st }}$ Ed. Springer. Berlin. 